\title{
ASPEKTY SPORTOWE W REPERTUARZE POLSKICH GRUP KABARETOWYCH
}

Humor jest elementem obecnym w życiu każdego człowieka. Umiejętność śmiechu jest cechą, która według wielu badaczy odróżnia człowieka od innych istot. Towarzyszy on ludziom od najmłodszych lat, kiedy to już w kołysce niemowlęta uśmiechają się, widząc zabawkę poruszaną przez kogoś lub rozpoznając znajome rysy twarzy. Humor jest obecny w życiu codziennym, podczas różnych bardziej i mniej skomplikowanych czynności, ponieważ jest nieodłącznym elementem życia.

Każdy człowiek chociaż raz brał udział w jakiejś grze lub zabawie, która na pewno wywoływała wiele emocji. Są to emocje skrajne, od radości zwycięstwa, po gorycz porażki, od zadowolenia z pokonania przeciwników, po smutek z niepowodzenia. Zabawa również towarzyszy człowiekowi od czasów dzieciństwa, kiedy to pełniła rolę socjalizacyjną. W dorosłym życiu stała się natomiast jego suplementem, poprzez możliwość zaspokojenia potrzeb rozrywki, które są bardzo istotne. Bez tego, człowiek nie mógłby normalnie funkcjonować. Istnieją gry i zabawy, których celem jest jedynie rozrywka, ale oprócz nich można spotkać takie, których celem jest edukacja. Są nimi chociażby gdy planszowe, czy zręcznościowe. Również gry karciane wymagają od gracza umiejętności logicznego myślenia, inteligencji oraz sprytu. Do tego zalicza się również gry, w których nie bierze się udziału bezpośrednio, ale jako obserwator, na przykład jeśli chodzi o gry zespołowe. Dobrym przykładem jest połka nożna, czy piłka siatkowa, które w naszym kraju są bardzo popularne, a ich rozgrywki gromadzą na stadionach, w halach sportowych i przez telewizorami wielu ich zwolenników. Poza wymienionymi rodzajami zabawy, istnieje również zabawa $\mathrm{w}$ formie oglądania, lub uczestniczenia $\mathrm{w}$ przedstawieniu teatralnym. Jest to rodzaj zabawy sklasyfikowanej przez R. Cailloisa jako „mimicry”. W tym rodzaju zabawy chodzi o zmianę swojego wizerunku poprzez przebranie, czy umowne rekwizyty i wcielenie się w kogoś innego. Do tego rodzaju zaliczają się wszelkie przedstawienia na deskach teatrów, czy innych scenach, na których

\footnotetext{
* Mgr Anna BańkA - Zakład Komunikacji Społecznej, Wydział Politologii, Uniwersytet Marii Curie-Skłodowskiej w Lublinie, e-mail: annabanka92@gmail.com.
} 
aktorzy na czas spektaklu odcinają się od swojej osobowości i wcielają się w powierzone im role, aby przekonująco przedstawić charakter postaci.

Do takiego rodzaju przedstawień zaliczają się również skecze kabaretowe, które są wykonywane na wielu scenach, a także transmitowane w telewizji. Są one dla wielu źródłem śmiechu, ponieważ stosują szereg mechanizmów tworzenia komizmu.

Komizm jest bardzo szerokim zagadnieniem, nad którym pochylali się badacze już w starożytności. Powstało wiele teorii, które miały na celu dokładny opis i definicję zjawiska komizmu. Badacze odróżnili je również od pojęć humoru i dowcipu, gdyż pojęcia te się łączą, ale nie można ich postrzegać jako tożsame. Komizm badany był przez reprezentantów wielu dziedzin, między innymi psychologów, socjologów, filozofów, a nawet lekarzy. Nie można przecież pominąć fizjologicznego aspektu śmiechu, który jest efektem komizmu. Teorie dotyczące zagadnienia komizmu są wyczerpujące, jednak niełatwym zadaniem było ustalenie jednej teorii, którą można by odnieść do każdego rodzaju komizmu. Wielu badaczy łączyło kilka teorii, aby w pełni zdefiniować zjawisko, jednak zawsze pojawiała się sytuacja, której nie można było ściśle określić i jednoznacznie przypisać do teorii.

Wśród teorii na temat odbioru komizmu, badacze wyróżnili typy osób, które posiadają pewne preferencje, co do dowcipów, które ich śmieszą. Zbadali również proces opowiadania dowcipów, w którym zostały wyodrębnione etapy, występujące kolejno po sobie. Są to etap przygotowania, opowiadania i reakcji odbiorców.

Jeżeli chodzi o zachowania wywołujące śmiech, to również zostały one sklasyfikowane i opisane. Mogą rozśmieszać zarówno inni ludzie, sytuacje, w których się znaleźli, ale także zwierzęta, które nie są tego świadome i nie robią tego w sposób zamierzony.

W komizmie wyróżniono wiele mechanizmów, które prowadzą do jego wywołania. Wśród nich wyróżnia się mechanizmy językowe, ale także dotyczące mimiki i gestów, czy rekwizytów obecnych na scenie.

Właściwa systematyzacja pojęcia gry i zabawy nie jest prosta, ponieważ istnieje wiele sposobów ich podziału ze względu na różne aspekty. Za kryteria można przyjmować przedmioty wykorzystywane przez uczestników, liczbę uczestników, miejsce rozgrywki, czy też charakter gry. D. B. Elkonin dowiódł, że w procesie ewolucji pojawiają się odmiany zabaw, które wskazują na przechodzenie zabaw w gry. Wyróżnił je na podstawie obecności i charakteru reguł działania, a są to:

- zabawy naśladowcze,

- udramatyzowane zabawy ruchowe nawiązujące do prostego tematu,

- tematyczne zabawy z prostymi zasadami,

- gry sportowe i gry ćwiczenia.

R. Caillois sugeruje podział na cztery kategorie, które określił na podstawie obecności elementów przypadku, współzawodnictwa, oszołomienia i naśladowania. Są to:

- alea,

- agon, 
- ilinx,

- mimicry.

Każdy z tych wariantów ma własne ściśle określone zasady

Pierwszą z kategorii wyróżnionych przez R. Caillois’a jest alea. Po łacinie słowo to oznacza grę w kości. Ten rodzaj gry polega na rozstrzygnięciu, które jest niezależne od gracza, ponieważ nie ma on na nie wpływu. Powodzenie uzależnione jest od losu. Przykładem jest gra w orła i reszkę, gra w kości, ruletka, czy bakarat. Idea tego rodzaju gry polega na oczekiwaniu, czy w danym momencie dopisze szczęście, ponieważ od zawodnika nie są wymagane żadne umiejętności, ani wysiłek mózgu lub mięśni. Zwycięzca nagradzany jest wprost proporcjonalnie do ryzyka, a sprawiedliwość, która jest celem sprowadza się do występowania idealnych warunków. Forma gry alea wyklucza walory zawodowe. Nie liczy się tu trud, zręczność, cierpliwość, ani kwalifikacje. Udział w takiej grze może być wielką porażką lub równie ogromnym sukcesem. Gracz nie liczy na siebie, ale na wszystko, odchylenie od normy, wskazówkę, czy znak, co obrazuje zdanie się na los. Wygrana pieniężna odgrywa większą rolę, kiedy większy jest również udział losu, czyli mniejsze szanse defensywy. Powód jest jednoznaczny. Chodzi o to, aby przynieść wygraną nie najinteligentniejszym, a wprost przeciwnie, dać równą możliwość wszystkim uczestnikom gry².

Kolejną grupą w klasyfikacji gier i zabaw jest agon. Tutaj istotny jest charakter zawodów, w których ważnym elementem jest rywalizacja w określonych warunkach i według określonych zasad. Opiera się na współzawodnictwie, gdzie istotna jest jedna cecha. Może nią być pomysłowość, zręczność, szybkość, czy pamięć i siła. Triumfator okazuje się najlepszy w tej, a nie innej kategorii zawodów. Najlepszym przykładem są tutaj zawody sportowe, gdzie rywalizują dwie jednostki lub zespoły, jak na przykład w piłce nożnej, tenisie, czy boksie, a także nieograniczona liczba zawodników, jak na przykład w lekkoatletyce. Zaliczyć można również gry, w których uczestnicy mają początkowo taką samą liczbę określonych elementów, jak na przykład szachy, warcaby, czy bilard. Jak widać, do kategorii agon zaliczają się zarówno gry, w których zawodnicy muszą wykazać się siłą mięśni, jak w zawodach sportowych, jak również gry, w których należy posłużyć się umysłem, jak w grze w szachy. Agon opiera się na osobistych zaletach i dąży do ich ujawnienia. Każdy z zawodników chcę pokazać przewagę w konkretnej dyscyplinie. W każdej z konkurencji jest wymagane odpowiednie wcześniejsze przygotowanie, wysiłek i wytrwałość. Porównując zjawisko agon i alea, widać zasadnicze różnice w wielu kwestiach. Pierwsze odwołuje się do własnej odpowiedzialności, kiedy alea, to zdanie się na los. Są również gry, które łączą w sobie elementy obu odmian, jak na przykład tryktrak, domino, czy gry w karty. To, co gracze dostaną w rozdaniu

${ }^{1}$ R. Caillois, Gry i ludzie, tłum. A. Tatarkiewicz, M. Żurowska, Oficyna Wydawnicza Volumen, Warszawa 1997, s. 22.

${ }^{2}$ Zob. Tamże, s. 25-26. 
jest uzależnione od losu, a dopiero później każdy z zawodników wykorzystuje swoje możliwości. Brydż jest przykładem gry, w której największą bronią gracza jest rozumowanie i umiejętności, dzięki którym może uzyskać najlepszy możliwy rezultat. Poker natomiast to rodzaj gry, w której ważna dla gracza jest przenikliwość i zimna krew. Wyniki agon pozostają niepewne i często absurdalne, przez co mogą być czysto przypadkowe, ponieważ zawodnicy mają równe szanse, natomiast ujęcie zawodów w reguły staje się przedmiotem zakładów, czyli przedmiotem alea. Agon i alea są sobie przeciwstawne i podlegają pewnemu prawu. Chodzi tu o wytworzenie pomiędzy graczami warunków całkowitej równości, której nie ma w realnym życiu. Gra zakłada, że każdy powinien mieć możliwość wykazania swoich zalet i umiejętności³.

Trzecią kategorią wyróżnioną przez autora analizy jest ilinx. Jest to kategoria polegająca na zamiarze oszołomienia poprzez chwilową destrukcję stabilnego odbioru i podyktowaniu przyjemnego lęku. Uczestnik gry ma osiągnąć pewnego rodzaju trans, w którym zatraca w pewnym stopniu poczucie rzeczywistości. R. Caillois w swojej książce podaje jako przykład tańczących derwiszy i meksykańskich voladores. Zachowanie tych pierwszych polega na obracaniu się wokół własnej osi przy coraz szybszych uderzeniach w bęben. Wywołuje to u nich pewien rodzaj paniki i stanu hipnotycznego, który zostaje osiągnięty poprzez nagły wybuch lęku przy żywiołowych obrotach ${ }^{4}$.

Ostatnia kategoria to mimicry, która określa tymczasowe zaakceptowanie pewnego hermetycznego, umownego i w pewnym stopniu nierzeczywistego świata. Tutaj w czasie gry lub zabawy człowiek nie poddaje się losowi, ani nie działa w określonym środowisku, ale przeistacza się w wyimaginowaną postać oraz przyjmuje zachowania dla niej charakterystyczne. Zgodnie z tymi zasadami jednostka uznaje, że wierzy, ze jest kimś innymi, a także pozwala do tego przekonać siebie lub próbuje o tym przekonać otoczenie. Na określony czas maskuje własną osobowość, zapomina o własnej naturze po to, aby udawać kogoś lub coś innego5. R. Caillois podkreśla, że wybrał termin mimicry dla podkreślenia elementarnego, organicznego charakteru bodźca, który w języku angielskim jest wykorzystywany do zdefiniowania mimetyzmu owadów.

Ujęcie słownikowe brzmi: ,mimikra: upodabnianie się organizmów do innych organizmów lub nieożywionych elementów znajdujacych się $w$ otoczeniu; rodzajem m. jest ubarwienie ochronne powodujace, że osobnik jest mniej widoczny dla potencjalnego drapieżcy lub przyszłej ofiary.".

Po przyjęciu hipotezy dotyczącej mimetyzmu owadów stwierdzić można, że mimetyzm jest odpowiednikiem zainteresowania, z jakim człowiek odgrywa

3 Zob. Tamże, s. 23-27.

${ }^{4}$ Zob. Tamże, s. 30-31.

${ }^{5}$ Zob. Tamże, s. 27.

${ }^{6}$ Nowa encyklopedia powszechna A-Z, red. J. Marcinek, Wydawnictwo Zielona Sowa, Kraków 2003, s. 560. 
jakąś rolę, czy udaje jakąś postać. U owadów maska, to element ciała, a nie, jak w przypadku człowieka rekwizyt. W każdym jednak przypadku ma na celu zmianę powierzchowności i wywołaniu reakcji u innych? Z Zachowania typu mimicry nie są obecne jedynie w dzieciństwie, ale pojawiają się również w wieku dojrzałym. Do tego zaliczają się wszelkie zabawy, w których obowiązuje przebranie lub maska i konsekwencje z tego wynikające, czyli wcielanie się w jakąś postać. Do tej kategorii należy zaliczyć grę aktorską oraz przedstawienia teatralne. Sedno stanowi tutaj fakt, że uchodzi się za kogoś innego, co pozwala na zabawę, przez co nie jest istotne oszukiwanie widza, bo dzieje się to w celu sprawienia mu przyjemności, a nie osiągnięcia negatywnych dla niego skutków. Tak, jak w czasie karnawału osoba przebrana za toreadora, czy markiza, nie ma na celu wmówienia nikomu, że naprawdę nim jest, ale korzysta ze swobody i faktu, że maska ukrywa osobę społeczną, a ujawnia prawdziwą osobowość. Jedynie zbieg lub szpieg przebierając się ma na celu wprowadzenie innych w błąd, gdyż nie robi tego dla zabawy ${ }^{8}$.

Jak pisze w swojej książce „Zabawa a rzeczywistość” Wincenty Okoń, każda gra jest zabawą, ponieważ wykazuje wszystkie jej cechy, ale nie każda zabawa jest grą. Pierwszą różnicą jest kwestia wyniku, który może być powodem sukcesu. Wynik zaczyna stawać się celem, co powoduje, że wzrasta jego znaczenie. Przyjemność, której dostarcza wysoki wynik osiągnięty w zabawie, zaczyna nabierać znaczenia takiego, jak w zabawie funkcjonalnej. Kiedy tak się dzieje zabawa przestaje być zwykłą, a przeradza się w konstrukcyjną lub staje się grą, ponieważ obie są zadowalające dla siebie samych, ale i dla wyniku?

Roger Callois w swojej książce „Gry i ludzie” określa termin gry jako pojęcie łączące zagadnienie wolności, granicy i inwencji. Dzieje się tak, ponieważ według jednego z najbardziej potocznych znaczeń, gra określa specyficzne działanie, ale również figury, symbole i akcesoria, które są niezbędne do przeprowadzenia danego działania. „Gra” określa także styl, czy zachowanie muzyka, wykonawcy lub aktora. Chodzi o cechy, które wyróżniają go spośród innych poprzez interpretowaną rolę. Wolność pozwala mu, mimo zobowiązania do określonego tekstu, na wyrażenie swojej mentalności ${ }^{10}$. Gry, których zasady opierają się na współzawodnictwie prowadzą do gier naśladowczych, czy sportów, natomiast te oparte na złudzeniu wskazują na rodzaj teatru ${ }^{11}$. Roger Caillois, definiując kategorię gier i zabaw wyróżnia czynności, które je charakteryzują. Są to: dobrowolność, fikcyjność, obecność elementu niepewności, wyodrębnienie, ujęcie w normy, oraz bezproduktywność. Dobrowolność polega tutaj na chęci udziału uczestnika, a nie przymusu. Rzeczywistość, która jest ukazana za pomocą gry lub zabawy może

${ }^{7}$ Zob. R. Caillois, Gry i ludzie..., s. 28.

${ }^{8}$ Zob. Tamże, s. 29.

9 Zob. W. Okoń, Zabawa a rzeczywistość, Wydawnictwa Szkolne i Pedagogiczne, Warszawa 1987, s. 160-163.

${ }^{10}$ Zob. R. Caillois, Gry i ludzie.., s. 6.

${ }^{11}$ Zob. Tamże, s. 10. 
być naśladowaniem rzeczywistości lub zupełnym oderwaniem od niej. W żadnym rodzaju rozgrywek, nie ma przewidzianego wyniku i odbywa się on w wyodrębnionej do tego przestrzeni i czasie. Każdorazowo obowiązują pewne zasady, do przestrzegania których są zobowiązani uczestnicy. Poza tym w czasie zabawy nie zostają tworzone jakiekolwiek nowe elementy, czy dobra ${ }^{12}$. Są to cechy uniwersalne odnoszące się do wielu rodzajów gier i zabaw. Pojęcie gry jest pojęciem bardzo szerokim, dlatego należy odpowiednio je skategoryzować, dla trafniejszej klasyfikacji poszczególnych rodzajów tego zjawiska.

Johan Huizinga zwraca uwagę na to, że zabawa w najbardziej podstawowych formach, a także w życiu zwierząt jest czymś znacznie więcej, niż tylko zjawiskiem o charakterze fizjologicznym. Zabawa jest czymś, co nie dąży do utrzymania jednostki przy życiu, ale nadaje mu sens ${ }^{13}$. W. Okoń również powołuje się na słowa J. Huizingi, który określa zabawę jako działanie lub zajęcie dobrowolne, które wykonywane jest w obrębie ustalonych granic, zarówno czasu, jak i miejsca. Uczestnicy zobowiązani są do przestrzegania dobrowolnie przyjętych i bezwzględnie wiążących reguł. Zabawie towarzyszy uczucie radości i napięcia, a także poczucie czegoś innego, niż rzeczywiste, zwyczajne życie ${ }^{14}$. J. Huizinga pisze, że gry, których zasady opierają się na współzawodnictwie prowadzą do gier naśladowczych, czy sportów, natomiast te oparte na złudzeniu wskazują na rodzaj teatru. Zabawa jest złożonym zjawiskiem kulturowym, które ściśle wiąże się z innymi zjawiskami życia zbiorowego. W języku greckim ,zabawa” ma trzy znaczenia. Pierwszym jest zabawa dziecięca, drugim, wesołość i beztroska, a trzecim walka, przejawiana wówczas podczas igrzysk olimpijskich. W języku łacińskim istnieje jedno określenie na zabawę i jest to wyraz „ludus" oznaczający grę, zabawę, ale i publiczne widowiska i igrzyska.

Igrzyska Olimpijskie są wydarzeniem sportowym cieszącym się dużą popularnością. Nie dotyczą jedynie płaszczyzny sportowej, ale przenikają także głęboko do kultury. Jednoczą nie tylko społeczność związaną ze środowiskiem sportowym, ale również całe narody i inne zbiorowości. Wiele polskich grup kabaretowych przedstawia wydarzenia sportowe, a także wszelkie ich aspekty.

Według Encyklopedii Powszechnej PWN kabaret miał dwa znaczenia, gdyż oprócz widowiska, tak nazywane było również samo miejsce, w którym prezentowane były skecze, a w spektaklu brali udział zawodowi aktorzy ${ }^{15}$. Natomiast według Słownika wyrazów obcych PWN słowo kabaret pochodzi od cambrette, co w starofrancuskim

${ }_{12}$ Zob. Tamże, s. 20.

${ }^{13}$ Zob. J. Huizinga, Homo ludens. Zabawa jako źródto kultury, tłum. M. Kurecka, W. Wirpsza, Wydawnictwo Aletheia, Warszawa 2007, s. 11-12.

${ }^{14}$ Zob. W. Okoń, Zabawa a rzeczywistość..., s. 26.

${ }^{15}$ Zob. Encyklopedia popularna PWN, red. R. J. Burek, Państwowe Wydawnictwo Naukowe, Warszawa 1997, s. 278. 
dialekcie oznacza dosłownie izdebkę, pokoik ${ }^{16}$. Na podstawie tych definicji można stwierdzić, że początkowo kabaret odnosił się do miejsca, a dopiero później jego znaczenie objęło również sam spektakl.

Pierwszym zbiorowym i najbardziej znanym w owych czasach był działający w latach 1905-1912 Zielony Balonik. Siedziba znajdowała się w pobliżu Akademii Sztuk Pięknych, za bramą Floriańską w Cukierni Lwowskiej Jana Michalika. Jeszcze zanim powstał kabaret, miejsce to gromadziło młodych i utalentowanych artystów. Zielony Balonik był pierwszym krokiem tworzenia się tradycji kabaretowej, obecnej do dziśn ${ }^{17}$.

Kabaret jest zatem młodym gatunkiem multimedialnym, który łączy elementy wielu dziedzin sztuki, w celu konstrukcji zabiegów i specyfiki gatunku kabaretu. Poprzez wykorzystanie wielu systemów semiotycznych, kabaret staje się samodzielnym rodzajem sztuki, nie może być postrzegany jako sztuka pośrednia, czy jako „niepełny” teatr, czy też literaturę mówioną. Istnieją tutaj zabiegi pobudzające znaczenia, które nie mogą być rozpatrywane jedynie jako środki teatralne, czy literackie.

Jürgen Henningsen utrzymuje, że kabaret korzysta z dwóch mechanizmów, jakimi są rozrywka i nauka, przez co gatunek ten ma charakter pedagogiczny. Aby zaistniał kabaret ważne są pewne zasady. Chodzi tu o:

- publiczność, która aktywnie uczestniczy w spektaklu;

- zasadę konstrukcyjną, według której występ kabaretowy składa się z powiązanych i następujących po sobie skeczów, co odróżnia kabaret od filmu, czy teatru;

- zasadę ograniczonych środków, która polega na ekonomii wykorzystywanych środków i redukcji znaczeń, ponieważ poprzez ograniczenie czasowe, kabaret nie może tworzyć iluzji, a jedynie nakreśla problem;

- kabaretowa rola, gdyż aktor kabaretowy gra równocześnie trzy role.

Role odgrywane jednocześnie przez kabareciarza, to: rola wynikająca z sytuacji przedstawionej w danej scenie kabaretowej, mająca wpłynąć na odbiorców, rola kabaretysty, a także rola osoby prywatnej, gdyż każdy aktor kabaretowy jest znany publiczności z imienia i nazwiska. J. Henningsen odróżnia kabaret od innych dziedzin sztuki, ponieważ jest on grą z obecnymi relacjami wiedzy, przyzwyczajeń i stereotypów poznawczych publiczności, ale jest też grą destrukcyjną, która nie popiera żadnej opcji politycznej. Badacz opisuje również metody kabaretowe, jako sposoby wpływu na świadomość. Do takich metod zalicza:

- trawestację, czyli przeciwieństwo parodii, w tym przypadku omawiane zjawisko zachowuje swoją treść, przy zmianie formy;

- parodię;

- karykaturę, czyli przerysowanie charakterystycznej cechy;

${ }^{16}$ Zob. Słownik wyrazów obcych, red. E. Sobol, Państwowe Wydawnictwo Naukowe, Warszawa 1997.

${ }^{17}$ Zob. I. Kiec, W kabarecie, Wydawnictwo Dolnośląskie, Wrocław 2004, s. 10-13. 
- demaskacja.

Realizacja tych założeń objawia się poprzez stosowanie zniekształcenia, kontrastu, kopiowania, substytucję lub likwidację. Oprócz tych metod, uczony wyróżnił mikrostruktury występujące w obrębie wyznaczonych metod. Nazywa je typowymi środkami kabaretowymi i zalicza do nich:

- wprowadzenie w błąd,

- pominięcie,

- abstrakcję i stylizację,

- gry językowe.

Przy pomijaniu celem jest opuszczenie elementu, aby widownia mogła uzupełnić go i tworząc w ten sposób puentę. Abstrakcja i stylizacja natomiast polega na prezentacji jednego szczegółu, a publiczność sama musi znaleźć punkt odniesienia. Gry językowe to kombinacja słów i ich znaczeń ${ }^{18}$.

Kabaret jest młodym gatunkiem multimedialnym, który łączy elementy wielu dziedzin. Jest wiele rodzajów skeczów kabaretowych, ale w każdym z nich chodzi o pewną grę. Grę aktorską, grę słów, czy też powiązanych ze sobą rekwizytów. Tematyka wystąpień grup kabaretowych jest różnoraka. Od polityki, poprzez życie codzienne, edukację, rozrywkę, a także sport. Wiele współczesnych grup kabaretowych skupia się na sporcie w swoich skeczach.

„Kabaret na Żywo" jest to program telewizyjny telewizji Polsat, który transmituje występ grup kabaretowych ze studia ATM w Warszawie. Pierwszy program odbył się 5.03.2017 roku. W drugim odcinku „Kabaret na Żywo” przeniósł się na sportową arenę. I to nie byle gdzie, bo do odkrytego niedawno nowego kraju, czyli do San Escobar. Tak na stronie Polsatu brzmi opis programu. „Sport to zdrowie, więc... śmiej się, kibicu! Z takim hastem wszyscy byli zdopingowani do dobrej zabawy. Tym bardziej, że o nasze samopoczucie zadbat - jak na igrzyska przystało - mistrzowski skład. Wśród zaproszonych gości znaleźli się Kabaret Koń Polski, Stanisław Tym, Kabaret na Koniec Świata, Kabaret Chyba, Budapesz oraz Stawomir Zapala. Przewodnikiem, komentatorem, gospodarzem oraz prowadzacym byt Marcin Wójcik z Kabaretu Ani Mru-Mru',19.

Wiosenne igrzyska w San Escobar rozpoczęły się od prezentacji uczestników. Imprezę uroczyście otworzył sam Prezydent Rzeczpospolitej Polskiej, w którego wcielił się współzałożyciel kabaretu Ani Mru Mru Marcin Wójcik. „Nasze igrzyska udowadniaja, że świat się zmienia. Udowadniają, że to dobra zmiana. Niemożliwe staje się możliwe”. Tak zacząt swoje przemówienie. „Dla sportowców-patriotów, dla sportowców wyklętych". Nawiązał w ten sposób do aktualnych wydarzeń w Polsce. „Jakie dyscypliny gwarantuja rozrywkę? Szachy, wyrąb drzew na czas, wyścigi

${ }^{18}$ Zob. M. Fleischer, Zarys teorii kabaretu, w: M. Fleischer, Konstrukcja rzeczywistości, Wydawnictwo Uniwersytetu Wrocławskiego, Wrocław 2002, s. 301-303.

$19 \mathrm{http} / /$ www.polsat.pl/news/2017-03-12/najsmieszniejsze-sa-igrzyska-w-san-escobar/kabaret-na-zywo/ [dostęp: 17.05.2017 20:35]' 
kolumn rządowych, strzelanie do bażantów i oczywiście narciarstwo. Będziemy też wybierać sędziów, a publikować tylko te dobre wyniki. Bo sport jest jak rzodkiew. Wszyscy lubia, ale niewielu uprawia". Następnie występowały grupy kabaretowe. Jeden z bohaterów Stanisław Górecki z Koszalina, skoczek narciarski, w którego wcielił się Leszek Malinowski z Kabaretu Koń Polski powiedział: „Skoki to spetnienie moich największych marzeń. Patrzę na nasza drużynę mistrzów świata, a to takie chudzinki są, więc uznałem, że brakuje kogoś o aerodynamicznych kształtach. Okazało się, że trenuje $w$ bloku, w którym mieszka, a jego mieszkanie znajduje się na ósmym piętrze. Następnie wystąpił Stanisław Tym, który zaprezentował legendarny monolog „Komentator sportowy”. „Halooo, halooo! Witam Państwa bardzo serdecznie". Wystąpiło również kilka amatorskich grup przedstawiających swoje skecze ${ }^{20}$.

W tym przypadku Igrzyskom Olimpijskim poświęcony był cały program kabaretowy emitowany w telewizji na żywo. Poza tym jest również wiele skeczów, które dotyczą tematyki sportowej. Przykładem może być Jerzy Kryszak, który w skeczu „Po olimpiadzie" komentuje występy Polaków na Letnich Igrzyskach Olimpijskich w 2012 roku. Jest niezadowolony i komentuje w bardzo krytyczny sposób, przy czym bardzo komiczny. Z ironią i sarkazmem opisuje poszczególne występy polskich zawodników. Opisuje wzruszenie, kiedy oglądał dekorację złotych medalistów z Polski, ale również aspekty reprezentantów, którym nie udało się zbyt wiele osiągnąć. Podaje przykład tenisistek, na które przyjemnie mu się patrzyło, ale niestety sportowych emocji nie mógł do tego dołączyć. Porównywał również siebie do sportowców, kiedy to próbował się w różnych dyscyplinach, jednak w żadnej nie miał szczęścia. Opisał swoje próby w rzucie oszczepem, młotem, pływaniu. „Dlaczego polscy ptywacy siegnęli dna? Bo za ptytkie mamy baseny" - komentuje tę dyscyplinę Jerzy Kryszak ${ }^{21}$.

Kolejnym skeczem jest wykonywany przez Pawła Dłużewskiego należącego do Kabaretu pod Egidą monolog komentujący Igrzyska Olimpijskie w Pekinie, które odbyły się w 2008 roku. Jest to parodia komentatora, który najpierw komentuje lekką atletykę, kiedy jeden z zawodników rzucając oszczepem, finalnie skacze o tyczce. Później Jelena Isinbajewa, która skacze o tyczce nie dostała zgody na lądowanie i zawisła na wysokości ponad 5 metrów. Dalej jest pływanie, gdzie Bartek Kizierowski, który rzekomo popłynął w przeciwnym kierunku i zmienił tor, a zawodnik bułgarski po wymianie ciosów z naszym zawodnikiem zgubił kąpielówki. Dalej Polak „płynie na grzbiecie... zawodnika z Francji...” jak mówi Paweł Dłużewski ${ }^{22}$.

Skeczem, który również dotyczy komentowania wydarzeń sportowych jest wspomniany już wcześniej występ Stanisława Tyma, który opowiada o trudnej pracy komentatora sportowego, w którego się również wciela, aby przedstawić

\footnotetext{
${ }^{20}$ Zob. Tamże, [dostęp: 17.05.2017 20:12]

${ }^{21} \mathrm{https} / / / \mathrm{www} . y o u t u b e . c o m / w a t c h ? v=a Y 5 w n t r V A Y o$ [dostęp: 17.05.2017 20:45]

${ }^{22}$ https://www.youtube.com/watch?v=bqPXRijnd9Q [dostęp: 17.05.2017 21:16]
} 
specyfikę tego zawodu i jego trudność. Autor uważa, że sprawozdawcy sportowi posługują się metajęzykiem, ponieważ zawsze używają specyficznych form do opisu rzeczywistości. Jak w poezji posługują się onomatopejami, metaforami, hiperbolami, wyrzutniami. Aby to zobrazować Stanisław Tym wchodzi w rolę komentatora i zakłada sobie na głowę stworzone przez siebie słuchawki, które zostały wykonane z plastikowych butelek. Wygląda przy tym komicznie, czym wzbudza zamierzoną reakcję wśród widowni. Następnie przedstawia mechanizm, na podstawie którego sprawozdawca mówiąc do mikrofonu słyszy w słuchawkach to, co mówi i jak trudne jest to, aby szybciej mówić to, co chce powiedzieć, zanim usłyszy to w słuchawkach, co w rzeczywistości nie jest możliwe, ale tutaj zostaje to wyśmiane. Autor przedstawia blaski i cienie pracy komentatora, który potrafi mówić prawie bez przerwy, wydawałoby się bez oddechu opisując wydarzenia, które obserwują. Najpierw mówi spokojnie, a kiedy coś ważnego zaczyna się dziać mówi coraz szybciej i coraz głośniej. W tym przypadku komentuje mecz piłki nożnej²3.

Poza skeczami dotyczącymi tematyki czysto olimpijskiej są również skecze dotyczące poszczególnych dyscyplin sportowych. Kabaret Ani Mru Mru stworzył powszechnie już chyba znany skecz o Adamie Małyszu, gdzie Marcin i Michał Wójcik wcielają się w komentatora skoków narciarskich i wspomnianego już skoczka Adama Małysza. Komentujący Marcin Wójcik w szczegółach opisuje zachowanie skoczka, a Michał Wójcik parodiuje jego zachowanie na belce startowej, podczas lotu i po wylądowaniu. Skoczek poprawia wąsy, nowe google i kombinezon. Kilkukrotnie komentujący powtarza: „Jeszcze nie, jeszcze nie...” kiedy skoczek już zniecierpliwiony oczekiwaniem chce wystartować. Kiedy skoczek wzbija się w powietrze, komentujący postanawia przypomnieć historię skoków narciarskich, ponieważ lot naszego zawodnika na pewno będzie długi. Podczas lotu skoczek pozdrawia publiczność. Opisuje postawę ciała zawodnika podczas lotu, kiedy to dłonie trzyma ściśle na pośladkach i inni zawodnicy spekulowali, czy nie ma przy sobie jakiegoś urządzenia, które mogłoby zwiększyć jego prędkość. Komentujący dodaje, że Adam ma tyle czasu, że gdyby palił papierosy, to mógłby to wtedy uczynić. Finalnie skok okazuje się bez zarzutu, a skoczek jest bardzo skromną osobą i „podrywa się do lotu”, kiedy podchodzi do niego dziennikarz ${ }^{24}$.

Skeczem, który również dotyczy skoków narciarskich jest skecz Kabaretu Młodych Panów o Piotrze Żyle. Jest on podobny do zaprezentowanego przez Kabaret Ani Mru Mru, ponieważ również przedstawia wszystkie etapy skoku zawodnika, ale tutaj dotyczy on zawodnika, który jest bardzo charakterystyczny przez swój sposób bycia i swoje zawsze zaskakujące i mało poważne odpowiedzi udzielane podczas wywiadów, przez co żartobliwie jest posądzany, że może być pod wpływem różnych środków. Ma również charakterystyczny śmiech. Ten skecz przedstawiony jest z perspektywy skoczka. Słyszymy jego myśli, które przez

\footnotetext{
${ }^{23}$ https://www.youtube.com/watch?v=ei33ICY3MGU [dostęp: 17.05.2017 21:27]

${ }^{24} \mathrm{https} / / /$ www.youtube.com/watch?v=81PnUe-h_1Q [dostęp: 17.05.2017 21:45]
} 
większą część skoku kierowane są gdzie indziej. Na przykład skoczek zastanawia się, czy zamknął pokój w hotelu, czy zapłacił za mini barek albo, że zapomniał wyłączyć żelazko. W czasie lotu podziwia widoki, obserwuje dreamlinery lecące nad nim i nuci piosenkę myląc jej tekst i autora. Na koniec nie chcąc pokazywać się w takim stanie decyduje, że na konferencję prasową uda się w kasku. Jest to nawiązanie do sytuacji, która rzeczywiście miała miejsce ${ }^{25}$.

Przedstawione skecze pokazują, że sport jest tematem cieszącym się dużą popularnością, jeśli chodzi o tematykę wystąpień grup kabaretowych. Poruszane są tu zagadnienia zarówno konkretnych startów zawodników na Igrzyskach Olimpijskich, starty na innych zawodach, przedstawione są sylwetki zawodników, którzy są powszechnie znani i charakteryzują ich ważne cechy, ale również sport pokazany jest od strony zwykłego widza, który odnosi się do tego, co zobaczył i czym nie jest zachwycony, jak również od strony sprawozdawcy sportowego, który, co prawda nie startuje w zawodach, ale jest często na miejscu i razem z zawodnikami i widownią bardzo emocjonalnie przeżywa rozgrywające się konkursy. W Polsce sport zawsze był dobrym tematem do dyskusji, ponieważ wiele osób sie nim interesuje i śledzi poczynania naszych reprezentantów. Autorzy skeczów odnoszą się zawsze do aktualnych wydarzeń, dlatego odbywające się Igrzyska Olimpijskie są komentowane tuż po ich zakończeniu, a skecze dotyczą sytuacji, które były najbardziej kontrowersyjne lub wzbudziły największą sympatię wśród odbiorców, jak na przykład komentarz Jerzego Kryszaka dotyczący nieudanych startów Polaków lub znany i przez wielu lubiany skoczek Adam Małysz, który jest skromny i tak też został przedstawiony przez grupę kabaretową.

W przytoczonych skeczach autorzy posługują się wieloma metaforami, obrazują poczynania zawodników, którzy nie zawsze radzą sobie na dużych turniejach sportowych. Odwołują się do takich aspektów sportowych, jak starty na dużych imprezach sportowych, zwycięstwa i porażki naszych reprezentantów, dekoracje i wręczanie złotych medali, pomyłki zawodników, a także ich udane występy, sylwetki zawodników, którzy są znani i lubiani lub bardzo charakterystyczni przez swój wygląd lub zachowanie. Nie brakuje również aspektu dotyczącego komentowania wydarzeń sportowych, nie tylko przez widzów, ale i przez sprawozdawców sportowych, których trudy wykonywania zawodu również zostały uwzględnione.

\section{BIBLIOGRAFIA}

Burek R. J., Encyklopedia popularna PWN, Państwowe Wydawnictwo Naukowe, Warszawa 1997.

Caillois R., Gry i ludzie, tłum. A. Tatarkiewicz, M. Żurowska, Oficyna Wydawnicza Volumen, Warszawa 1997.

Fleischer M., Zarys teorii kabaretu, w: M. Fleischer, Konstrukcja rzeczywistości, Wydawnictwo Uniwersytetu Wrocławskiego, Wrocław 2002

\footnotetext{
${ }^{25}$ https://www.youtube.com/watch?v=2agZ0OatEew [dostęp: 17.05.2017 22:22]
} 
Huizinga J., Homo ludens. Zabawa jako źródto kultury, tłum. M. Kurecka, W. Wirpsza, Wydawnictwo Aletheia, Warszawa 2007.

Kiec I., W kabarecie, Wydawnictwo Dolnośląskie, Wrocław 2004.

Marcinek J., Nowa encyklopedia powszechna A-Z, Wydawnictwo Zielona Sowa, Kraków 2003.

Okoń W., Zabawa a rzeczywistość, Wydawnictwa Szkolne i Pedagogiczne, Warszawa 1987.

Sobol E., Stownik wyrazów obcych, Państwowe Wydawnictwo Naukowe, Warszawa 1997.

http://www.polsat.pl/news/2017-03-12/najsmieszniejsze-sa-igrzyska-w-san-escobar/kabaret-na-zywo/

https://www.youtube.com/watch?v=aY5wntrVAYo

https://www.youtube.com/watch?v=bqPXRijnd9Q

https://www.youtube.com/watch?v=ei33ICY3MGU

https://www.youtube.com/watch?v=81PnUe-h_1Q

https://www.youtube.com/watch?v=2agZ0OatEew

\section{Streszczenie}

Termin gry określa styl lub zachowanie muzyka, wykonawcy czy aktora, gdyż pewne cechy wyróżniają go spośród innych poprzez interpretowaną rolę. Gry, których zasady opierają się na współzawodnictwie to gry naśladowcze, czy sporty, natomiast te oparte na złudzeniu wskazują na rodzaj teatru. Zabawa jest złożonym zjawiskiem kulturowym, które ściśle wiąże się z innymi zjawiskami życia zbiorowego. W języku łacińskim zabawę określa „ludus” oznaczające grę, zabawę, ale i publiczne widowiska i igrzyska. Igrzyska Olimpijskie są wydarzeniem sportowym cieszącym się dużą popularnością. Nie dotyczą jedynie płaszczyzny sportowej, ale przenikają także głęboko do kultury. Jednoczą nie tylko społeczność związaną ze środowiskiem sportowym, ale również całe narody i inne zbiorowości. Wiele polskich grup kabaretowych przedstawia wydarzenia sportowe obrazując występy polskich reprezentantów, sukcesy, porażki, najbardziej znane i charakterystyczne sylwetki sportowców, a także zawód sprawozdawcy sportowego.

Słowa kluczowe: sport, kabaret, skecz, Igrzyska Olimpijskie.

\section{ASPECTS OF SPORT IN THE WORKS OF POLISH CABARET GROUPS}

\section{Sum mary}

The term game defines the style or behavior of a musician, performer, or actor, because certain features distinguish him from others through the interpreted role. Games whose rules are based on competition are mimic games or sports, while those based on illusion concern the type of theater. Fun is a complex cultural phenomenon that is closely related to other phenomena of collective life. In Latin, the term "ludus" means game, play, but also public shows and games. The Olympic Games are a popular sporting event. They do not only affect the sport field, but they penetrate deeply into the culture. They unite not only the community associated with the sports environment, but also entire nations and other communities. Many Polish cabaret groups present sporting events depicting performances of Polish representatives, successes, failures, the most famous athletes as well as the profession of the sports reporter.

Keywords: Sport, cabaret groups, sketch, The Olympic Games. 